Karolina Wawok

\title{
Sprawozdanie z działalności studentów Instytutu Historii Sztuki i Kultury Uniwersytetu Papieskiego Jana Pawła II
}

Większość studentów Instytutu Historii Sztuki i Kultury to członkowie Koła Naukowego Historyków Sztuki Uniwersytetu Papieskiego Jana Pawła II. Koło Naukowe umożliwia studentom rozwijanie własnych pomysłów, talentów oraz przedsięwzięć, pomaga także w staraniach o dotacje projektów. Jest ono obecnie jednym z największych i najprężniej działających kół naukowych na Uniwersytecie Papieskim. Zrzeszeni w nim są zarówno studenci historii sztuki, jak i ochrony dóbr kultury. Nad całością czuwa zarząd złożony z prezesa, wiceprezesa, skarbnika, sekretarza i komisji rewizyjnej. Wybierany jest corocznie na walnym zebraniu członków Koła. Opiekunem Koła od momentu jego założenia jest dr Józef Skrabski.

Rozgłos Instytutowi przynoszą organizowane lub współorganizowane przez studentów konferencje naukowe. W roku akademickim 2011/2012 studenci zorganizowali konferencję „Muzealia w konserwacji”, współorganizowali seminarium dotyczące sztuki i kultury duchowej cystersów oraz konferencję „Śmierć sztuki sakralnej”. Ponadto studenci Instytutu zaangażowani byli w pomoc przy obsłudze konferencji „Sztuka po Trydencie”, organizowanej przez Instytut Historii Sztuki i Kultury.

Ciekawym doświadczeniem była organizacja konferencji „Śmierć sztuki sakralnej” z cyklu „Wysoka Kultura”. Odbyła się ona 1 grudnia 2011 roku w Instytucie Historii Sztuki i Kultury UPJPII przy ul. Sławkowskiej 32. Studenci Instytutu, nawiązując współpracę z artystą i pomysłodawcą projektu „Wysoka Kultura” Łukaszem Murzynem, postanowili zmierzyć się z problemami sztuki sakralnej we współczesnym świecie. Poruszane zagadnienia zainteresowały historyków sztuki, artystów oraz wiele osób związanych ze sztuką i kulturą. Zastanawiano się nad relacjami sztuki sakralnej ze współczesną kulturą oraz jej rozwojem. Kilkoro prelegentów podjęło się próby przedstawienia swoich przemyśleń i wniosków 
na ten temat. Referat zaprezentował między innymi ks. prof. Tadeusz Dzidek (UPJPII, Kraków), przedstawiając typologię sztuki sakralnej - dyskusja z Paulem Tillichem. Łukasz Murzyn (artysta, lider Projektu Wysoka Kultura) podjął problem perspektyw „nowego otwarcia” w sztuce sakralnej. Krzysztof Siatka (historyk sztuki i kurator artystyczny - Galeria Sztuki Współczesnej Bunkier Sztuki w Krakowie) mówił o wykorzystaniu nowych technologii i sposobów obrazowania we współczesnej sztuce sakralnej. Niezwykle interesująca okazała się także żywa dyskusja, którą wzbudziła owa tematyka.

17 maja 2012 roku studenci Instytutu wraz z ks. dr. hab. Dariuszem Taborem oraz Opactwem Cystersów w Mogile zorganizowali III Seminarium Sztuki i Kultury Duchowej Cystersów. Obrady miały miejsce w siedzibie Instytutu Historii Sztuki i Kultury. Już trzecia edycja konferencji pokazała, jak ważne jest dziedzictwo cystersów, zarówno to materialne, jak i duchowe. Działalność cystersów na terenie Polski to setki lat historii zapisanej w zabytkach architektury, piśmiennictwa czy w ich kulturze duchowej. Prezentację referatów rozpoczęto od problematyki rozważań św. Bernarda z Clairvaux o sztuce sakralnej w interpretacji Arnolda Roncégo, jako źródła rozproszeń dla przywiązanych do marności świata, którą przedstawił prof. dr hab. Piotr Krasny (Instytut Historii Sztuki Uniwersytetu Jagiellońskiego). Dr Ewa Herniczek (Uniwersytet Pedagogiczny w Krakowie) stawiała pytania o rolę obrazów w kulturze artystycznej i duchowej cystersów. Ks. dr hab. Dariusz Tabor CR (Instytut Historii Sztuki i Kultury Uniwersytetu Papieskiego Jana Pawła II) zaprezentował referat pt. Obrazowa legenda $o$ św. Jadwidze: księga $z$ ducha cysterskiego. Całość konferencji dopełniła problematyka referowana przez dr. hab. Pawła Pencakowskiego (Akademia Sztuk Pięknych w Krakowie), dotycząca modernizacji średniowiecznych kościołów cysterskich. Niezwykle owocna była dyskusja podsumowująca referaty, która uzmysłowiła wiele interesujących aspektów sztuki i kultury cysterskiej. Studenci naszego Instytutu szczególnie zainteresowali się tą tematyką. Każdej edycji konferencji towarzyszył objazd zabytkoznawczy: I edycja (2010 r.) - Rudy Wielkie, II edycja (2011 r.) - Jemielnica, III edycja (2012 r.) - Jędrzejów. Ponadto w kwietniu 2011 roku zorganizowano trzydniowy objazd naukowy po opactwach cysterskich Małopolski i Górnego Śląska. Odwiedzono między innymi takie miejsca, jak Wąchock, Mogiła czy Sulejów.

„Muzealia w konserwacji” to konferencja zainicjowana przez studentów, którzy chcieli pogłębić swoje zainteresowania dotyczące pracy z muzealiami. Sukces pierwszej edycji zachęcił organizatorów do powtórzenia tematyki sesji. Już druga jej edycja odbyła się 22 maja 2012 roku w auli Wyższego Seminarium Duchownego przy ul. Podzamcze 8 . Konferencja miała za zadanie przybliżyć studentom 
zagadnienia dotyczące pracy konserwatora, technik, jakich używają, oraz przypadków, z jakimi się spotykają. Miała też uzmysłowić słuchaczom, jak ważne jest zachowanie dziedzictwa kulturowego dla przyszłych pokoleń. Konieczne jest więc stosowanie odpowiednich zabiegów prewencyjnych, z którymi, dzięki bogatemu materiałowi ilustracyjnemu, mogli zapoznać się słuchacze. Tematykę rozważań rozpoczął dr hab. Paweł Pencakowski (Akademia Sztuk Pięknych w Krakowie). Poruszył on bardzo ważny temat, dotyczący współpracy historyka sztuki i konserwatora. Dr Natalia Krupa (Pracownia Konserwacji Tkanin - katedra na Wawelu) zaprezentowała referat pt. Włoskie tkaniny aksamitne z XV i XVI wieku $w$ zabytkowych tekstyliach ze skarbca katedry na Wawelu - interdyscyplinarny charakter badań droga do ustalenia chronologii zabytku. Mgr Karolina Sarkowicz (Uniwersytet Papieski Jana Pawła II w Krakowie) przedstawiła przykłady konserwacji tkanin w pracowni Opificio delle Pietre Dure we Florencji, opierając się na własnych doświadczeniach z pracy w tamtejszym miejscu. Mgr Zofia Maniakowska-Jazownik (Pracownia Konserwacji Papieru i Skóry Muzeum Narodowego w Krakowie) w swoim referacie położyła szczególny nacisk na działania prewencyjne w ochronie obiektów na papierze. Problemy konserwatorskie związanie z wnętrzem kościoła pw. św. Elżbiety we Wrocławiu po pożarze w 1976 roku przedstawił dr Jan Żelbromski (Szkoła Wyższa Rzemiosł Artystycznych i Zarządzania we Wrocławiu). Natomiast do konserwacji obiektów małej architektury nawiązała Paula Musiał (Akademia Sztuk Pięknych w Krakowie), mówiąc o ołtarzu kamiennym z kaplicy Fotygów w Chęcinach. Referaty przedstawione na konferencji były więc bardzo różnorodne. Obejmowały konserwację zarówno tkanin, papieru, jak i obiektów architektury. Zastanawiano się także nad współpracą konserwatorów $\mathrm{z}$ historykami sztuki oraz nad innymi aspektami pracy $\mathrm{z}$ muzealiami. Konferencja stanowiła zatem doskonałe uzupełnienie zeszłorocznej edycji. Zgromadziła dużą widownię. Pozwoliła również na wymianę poglądów pomiędzy studentami konserwacji, historii sztuki i ochrony dóbr kultury oraz umożliwiła nawiązanie przez studentów kontaktów ze specjalistami w dziedzinie konserwacji. Planowana jest kolejna edycja w przyszłym roku.

Warto także wspomnieć o trzech edycjach konferencji „Pogranicza chrześcijaństwa” organizowanej w latach 2009, 2010 i 2011. Inicjatywa studentów naszego Instytutu, we współpracy ze studentami Instytutu Historii Sztuki Uniwersytetu Jagiellońskiego, odbiła się echem nie tylko w Polsce, ale i za granicą. Świadczą o tym zgłoszenia na trzecią edycję konferencji z Rosji czy Ukrainy. Był to niewątpliwie jeden $\mathrm{z}$ największych sukcesów odniesionych przez studentów Instytutu. Konferencja zgromadziła najlepszych badaczy z ponad 20 uniwersytetów i instytucji, takich jak m.in. Muzeum Archeologiczne w Krakowie, Muzeum Archeologiczne 
w Warszawie, Uniwersytet Śląski, Uniwersytet Gdański, Uniwersytet Jagielloński, Uniwersytet Opolski, Uniwersytet im. Adama Mickiewicza, Uniwersytet Warszawski, Politechnika Wrocławska, Uniwersytet Łódzki, Uniwersytet Kardynała Stefana Wyszyńskiego, Katolicki Uniwersytet Lubelski Jana Pawła II czy też Instytut Kultur Śródziemnomorskich i Orientalnych PAN. Łączyła takie dyscypliny naukowe, jak historia sztuki, archeologia, filozofia, teologia, historia. Najważniejsza była jednak III edycja konferencji, gdyż została dedykowana śp. prof. Hannie Szymańskiej, w podziękowaniu za jej wkład w rozwój naukowy studentów oraz wsparcie okazane projektowi konferencji. Tematyka oscylowała wokół pojęć: symbol, znak, ornament. Okazała się ona niezwykle ciekawa, gdyż zgromadziła tłum słuchaczy. Wystąpieniom towarzyszyły bardzo ciekawe i ożywione dyskusje. Nawiązano wiele kontaktów z ośrodkami badawczymi w całej Polsce.

Studenci są także inicjatorami spotkań z artystami oraz wybitnymi naukowcami. Tematyka organizowanych spotkań jest bardzo różnorodna, obejmuje zagadnienia zarówno z dziedziny historii sztuki, jak i architektoniczne, konserwatorskie czy historyczne. 22 marca 2011 roku odbyło się spotkanie i dyskusja z prof. Laurie Koloski, historykiem kultury politycznej XX wieku z Uniwersytetu „William and Mary” z Williamsburga (Virginia, USA), pod tytułem „Remembering communism”. Temat dyskusji był związany z komunizmem w Europie Środkowo-Wschodniej. Spotkanie odbyło się w języku angielskim.

24 maja 2011 roku zorganizowano spotkanie z artystą projektantem Bartoszem Muchą w Instytucie Historii Sztuki i Kultury. Tematyką spotkania były „52 leniwe tygodnie”, czyli prezentacja projektu trwającego 52 tygodnie, w czasie którego artysta zaprojektował 52 obiekty paraarchitektoniczne. Otrzymany katalog obiektów jest do udostępnienia w siedzibie zarządu Koła.

Domeną Koła Naukowego jest organizacja objazdów naukowych. Jest to nieodłączna część kształcenia studentów Instytutu. Pozwalają one poszerzyć horyzonty myślowe, wykorzystać wiedzę w praktyce, zapoznać się z historią, kulturą i sztuką różnych regionów Polski i Europy. W roku akademickim 2011/2012 studenci Instytutu wraz z wykładowcami zorganizowali następujące objazdy naukowe: Rzym; objazd „Szlakiem zabytków techniki i barokowych perełek”; Wiedeń; „Kultura artystyczna Wielkopolski” oraz objazd „Skarby Transylwanii”. Ważnym elementem każdego wyjazdu jest obowiązkowe przygotowanie referatu przez każdego uczestnika, a później wygłoszenie go na miejscu, często w formie oprowadzania po obiekcie. Zakres tematyczny opracowań proponują opiekunowie dydaktyczni objazdu. Obejmuje on historię danego terenu lub kraju, dzieje obiektów, zwraca się również uwagę na aspekty kulturowe czy społeczne danego regionu. Poprzez takie wyjazdy studenci wypracowują sobie wrażliwość 
estetyczną i artystyczną. Kształtują także umiejętności analizy ikonograficznej, interpretacji dzieł i zabytków sztuki. Przyszli muzealnicy i historycy sztuki mają sposobność zapoznania się z różnymi pomysłami aranżacji przestrzeni wystawienniczych oraz różnego typu zabiegami prewencyjnymi, stosowanymi w celu ochrony zabytków i muzealiów. Wyjazdy te są ponadto doskonałą okazją do zebrania bogatego materiału fotograficznego oraz źródłowego, potrzebnego do podejmowanych przez studentów badań.

Objazd zabytkoznawczy do Rzymu odbył się w dniach 30 października 6 listopada 2011 roku. Adresowany był do studentów III roku kierunku ochrony dóbr kultury i historii sztuki. Opiekunem objazdu był dr Michał Myśliński. Wyjazd taki odbywa się corocznie dzięki pomocy finansowej Wielkiego Kanclerza naszej Uczelni ks. kardynała Stanisława Dziwisza. Podczas wyjazdu studenci mieli okazję zapoznać się ze sztuką od starożytności aż po współczesność, tak więc każdy znalazł coś z zakresu swoich zainteresowań. Poprzez zabytki studenci poznali historię, sztukę i kulturę Wiecznego Miasta. Oprócz starożytnego centrum mieli też możliwość zwiedzania m.in. ruin Ostii - antycznego miasta portowego. Bogate kolekcje muzealne pozwoliły na bezpośredni kontakt z dziełem sztuki. Niezliczona liczba włoskich zabytków oraz muzeów to świadectwo kulturowe dziejów całej Europy, które zasługuje na uwagę każdego. Wszyscy wrócili do Polski bogatsi o nowe doświadczenia.

W dniach 16-17 grudnia 2012 roku odbył się objazd naukowy „Szlakiem zabytków techniki i barokowych perełek”. Opiekunami objazdu byli: dr Józef Skrabski, dr Sławomir Dryja oraz dr Barbara Ciciora. Objazd ten świadczy o zainteresowaniach studentów, które oscylują nie tylko wokół sztuki, ale i również innych dziedzin z nią związanych. Odwiedzono wiele miejscowości znajdujących się głównie na terenie województwa świętokrzyskiego, m.in. Kielce, Bodzentyn, Tokarnię.

Wiedeń był kolejnym celem wyjazdowym studentów Instytutu. Objazd zorganizowano w dniach 11-16 marca 2012 roku. Jego celem było zapoznanie się z dziedzictwem kulturowym Wiednia oraz całej monarchii austro-węgierskiej. Odwiedzono takie obiekty, jak kościół św. Karola Boromeusza, pałac Belvedere, Pałac Schönbrunn, kościół św. Piotra i Pawła, katedra św. Szczepana, ale i także budowle secesyjne i modernistyczne, jak Pawilon Secesji oraz muzea, np. Kunsthistoriches Museum. Opiekunami objazdu byli: ks. dr hab. Dariusz Tabor i dr Małgorzata Reinhard-Chlanda.

Objazd naukowy „Kultura artystyczna Wielkopolski” odbył się w dniach 9-14 kwietnia 2012 roku. Przy organizacji tego wyjazdu studenci naszego Instytutu współpracowali ze studentami oraz wykładowcami z Akademii Sztuk Pięknych 
w Krakowie. Zwiedzono następujące miejscowości: Biskupin, Poznań, Rogalin, Kórnik, Ląd, Gostyń, Leszno, Rydzyna, Gniezno, Trzemeszno, Mogilno, Strzelno, Kruszwica, Włocławek i Płock. W Wielkopolsce, regionie ważnym dla państwowości polskiej, studenci zapoznali się z zabytkami począwszy od okresu średniowiecza i panowania Piastów, poprzez renesans, barok, aż po współczesne centra sztuki. Poruszono też problemy związane z rozwojem religii chrześcijańskiej na terenach polskich. Wyjazd ten był doskonałą okazją do wymiany poglądów pomiędzy studentami dwóch różnych uczelni oraz możliwością nawiązania współpracy, która będzie w najbliższym czasie kontynuowana. Dzięki cennym uwagom opiekunów: dr. Józefa Skrabskiego, dr Barbary Ciciory i dr. Sławomira Dryi, wyjazd ten był cennym doświadczeniem.

Największym wyjazdem, ze względu na liczbę uczestników, zorganizowanym w roku akademickim 2011/2012 był objazd naukowy "Skarby Siedmiogrodu”. Udział wzięło w nim ponad 50 studentów Instytutu Historii Sztuki i Kultury. Opiekunami wyjazdu byli: dr Piotr Grotowski oraz dr Natasza Styrna. Trasa wiodła przez malownicze tereny Rumunii. Studenci mieli sposobność zwiedzenia takich miejscowości, jak: Kluż-Napoka, Alba Iulia, Biertan, Mosna, Medias, Fagarasz, Cirta, Brasov, Sibiu, Sebes, Hunedoara. Kraj ten uchodzi za jeden z najbardziej tajemniczych terenów Europy. Kojarzony jest najbardziej z postacią Drakuli, ale to właśnie tam zachowało się mnóstwo zabytków, raczej rzadko odwiedzanych przez turystów. Dzięki mieszance różnych kultur (teren zamieszkują Rumuni, Węgrzy i inne narodowości) oraz religii (katolicy, ewangelicy, prawosławni, żydzi) można było zaobserwować tam wiele ciekawych zjawisk kulturowych. Szczególnie interesujące były zamki oraz kościoły warowne znajdujące się w tym rejonie Rumunii. Studenci przedstawili bogate referaty przedstawiające historię kraju, ważne osobistości oraz poszczególne zabytki. Rumunia była pozytywnym zaskoczeniem dla większości uczestników. Bogactwo zabytków oraz kultura tego kraju zachwyciła wszystkich. Spotkaliśmy się z wielką przychylnością miejscowych, którzy chętnie opowiadali o historii swojego regionu. Całości dopełniła malowniczość krajobrazu Karpat. Wspólny wyjazd pozwolił na zapoznanie się i zrozumienie zjawisk zachodzących w rumuńskiej kulturze i sztuce.

Ważnym projektem współorganizowanym od lat przez Koło Naukowe jest inwentaryzacja kościołów i klasztorów Archidiecezji Krakowskiej. Celem projektu, którego opiekunem jest dr Józef Skrabski, jest opracowanie wszystkich kościołów i klasztorów archidiecezji i stworzenie nowoczesnej bazy danych, która ułatwiłaby badania historyków, historyków sztuki i nie tylko. Studenci w ramach wyjazdów dokonują opisów wyposażenia ruchomego i nieruchomego w danych obiektach, a później opracowują i archiwizują dane. Powstaje również bogaty 
materiał fotograficzny. W ciągu ostatnich lat zinwentaryzowano obiekty m.in. w dekanacie zatorskim, babickim, krzeszowickim, niepołomickim, wielickim, czernichowskim i mogilańskim. Prace inwentaryzacyjne nadal trwają.

W roku akademickim 2011/2012 studenci powzięli inicjatywę stworzenia własnego czasopisma „Vide”, na łamach którego mogliby publikować własne artykuły z zakresu historii sztuki i dziedzin z nią korespondujących, a także recenzje, omówienia wystaw i sprawozdanie z Inwentaryzacji kościołów Archidiecezji Krakowskiej. Nazwa (z łac. vide - patrz) ma zwrócić uwagę na zmysł wzroku, który jest najważniejszym narzędziem poznawczym dzieła sztuki, oraz na prace badawcze studentów. Projekt ten spotkał się z przychylnością władz Instytutu oraz Wydziału Historii i Dziedzictwa Kulturowego. Czasopismo przewidziane jest jako rocznik, uzyska własny numer ISSN, a nazwa wpisana zostanie do Rejestru dzienników i czasopism. Obecnie trwają prace redakcyjne nad pierwszym numerem. Projekt ten motywuje studentów do działalności naukowej, upowszechnia ją, a także daje sposobność zaistnienia w środowisku naukowym.

Studenci dbają również o dobrą atmosferę w Instytucie. Corocznie organizowane są spotkania opłatkowe oraz Bale Historyka Sztuki. Dzięki tym inicjatywom społeczność studencką wyróżnia bardzo dobra współpraca ze środowiskiem naukowym Instytutu.

Jednak większość przedsięwzięć realizowanych przez Koło Naukowe nie mogłaby się odbyć bez wsparcia finansowego, jakiego udziela nam przede wszystkim Fundacja im. Św. Królowej Jadwigi oraz Rada Kół Naukowych UPJPII. Ponadto wielkiego wsparcia udzielają nam wykładowcy Uniwersytetu oraz Dyrekcja Instytutu Historii Sztuki i Kultury, która dba o rozwój studentów oraz stwarza warunki do realizacji ich inicjatyw. 